\title{
Ortaokul Öğrencilerinin Matematiksel Düşünme Aşamaları İle Matematik Öz Yeterlikleri Arasındaki İlişkinin İncelenmesi
}

\author{
Merve Tüzün $^{1}$ (iD) Ahmet Cihangir ${ }^{2}$ \\ Necmettin Erbakan Üniversitesi, Ahmet Keleşoğlu Eğitim Fakültesi, İlköğretim Matematik Eğitimi Bilim Dal1, Konya, Türkiye \\ mrv_tuzun@hotmail.com (Sorumlu Yazar/Corresponding Author) \\ Dr. Öğr. Üyesi, Necmettin Erbakan Üniversitesi, Ahmet Keleşoğlu Eğitim Fakültesi, Matematik Eğitimi Anabilim Dalı, Konya, \\ Türkiye acihangir@erbakan.edu.tr
}

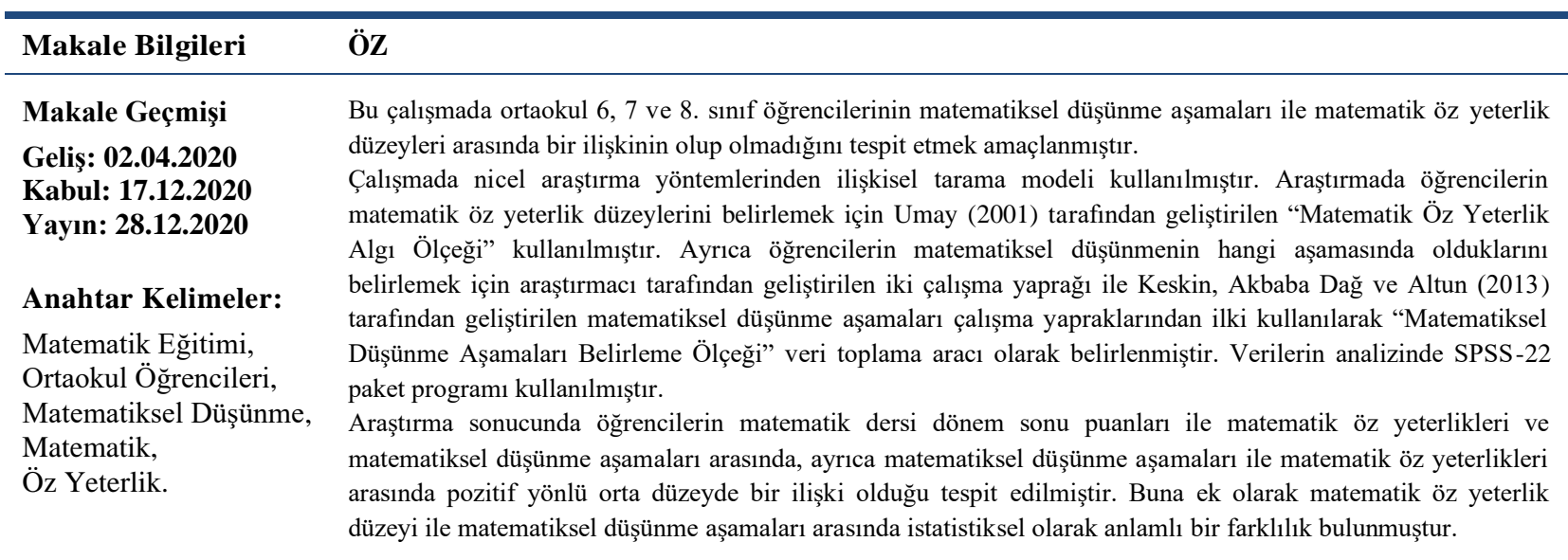

\section{Analysis of the Relation Between Mathematical Thinking Stages and Mathematics Self Efficacy of Secondary School Students}

\begin{tabular}{|c|c|}
\hline Article Info & ABSTRACT \\
\hline $\begin{array}{l}\text { Article History } \\
\text { Received: } \mathbf{0 2 . 0 4 . 2 0 2 0} \\
\text { Accepted: } \mathbf{1 7 . 1 2 . 2 0 2 0} \\
\text { Published: } \mathbf{2 8 . 1 2 . 2 0 2 0} \\
\text { Keywords: } \\
\text { Mathematical } \\
\text { Education, } \\
\text { Secondary School } \\
\text { Students, } \\
\text { Mathematical Thinking, } \\
\text { Mathematics, } \\
\text { Self-Efficacy. }\end{array}$ & $\begin{array}{l}\text { The purpose of this study, is to determine whether there is a relationship between the mathematics self efficancy } \\
\text { of } 6 \text { th,7th and 8th grade secondary school students towards and their mathematical thinking stages. In this study, } \\
\text { relational survey model has been used which is one of the quantitative research methods. } \\
\text { In this research "Mathematics Self- Efficacy Test" has been used, which is developed by Umay (2001) to } \\
\text { determine the stages of mathematics self- efficacy of students. Moreover, two worksheets which has been } \\
\text { developed by the researcher and one of the worksheets developed by Keskin, Akbaba Dag and Altun (2013) has } \\
\text { been used in order to determine the mathematical thinking stages of the students and also "The Defining Scale of } \\
\text { Mathematical Thinking" has been used as a data collection tool. SPSS-22 package program was used to analyze } \\
\text { the data. } \\
\text { As a result of the research, it has been determined that there is a moderate positive relationship between the } \\
\text { mathematics semester end scores and mathematics self-efficacy and mathematical thinking stages, as well as } \\
\text { between mathematical thinking and mathematics self-efficacy. } \\
\text { In addition, a statistically significant difference was found between mathematics self-efficacy level and } \\
\text { mathematical thinking stages. }\end{array}$ \\
\hline
\end{tabular}

Atıf/Citation: Tüzün, M. ve Cihangir, A. (2020). Ortaokul Öğrencilerinin Matematiksel Düşünme Aşamaları İle Matematik Öz Yeterlikleri Arasındaki İlişkinin İncelenmesi, Ahmet Keleşoğlu Eğitim Fakültesi Dergisi, 2(2), 210228. 


\section{GİRIŞ}

Matematik; büyüklük, sayı, şekil ve bunlar arasındaki örüntü ve düzenlerin bilimi, şekiller ve sayılar üzerine kurulmuş evrensel bir dildir. Bilgiyi işlemeyi, üretmeyi, tahminlerde bulunmayı ve problem çözmeyi ihtiva eder (MEB, 2018).

Umay (2003)'e göre matematik, düşünmeyi geliştirir ve eğitimin yapı taşlarından en önemlisini oluşturur. Ardahan (1990)'a göre matematik, insanların karşılaşabilecekleri her tür problemi çözmek için kullandığı düşünceler bütünüdür. Baykul (2009)' a göre ise matematik, birbirini takip eden genellemeler ve soyutlamalar süreci olarak geliştirilen bağıntıları içeren sistemdir.

Matematik; düşüncenin tümdengelimli bir iletişim yolu ile sayılar, geometrik şekiller, fonksiyonlar, uzaylar ve benzer soyut varlıkların özelliklerini ayrıca bunların arasında kurulan ilişkileri inceleyen bilimler grubunun genel adidır (Altun, 2002).

\section{Matematiksel Düşünme}

Literatürde araştırmacılar matematiksel düşünmeyi farklı şekillerde tanımlamışlardır. Henderson ve diğerleri (2004)'a göre matematiksel düşünme; problemlerin çözümünde matematiksel süreçlerin doğrudan ya da dolaylı olarak uygulanmasıdır. Burton (1984) ise matematiksel düşünmenin matematiğin konusu hakkında düşünme değil; bilinen matematiksel dinamiklerin, süreçlerin ve belli işlemlerin fonksiyonu olan bir düşünme biçimi olduğunu ifade etmiştir.

Mason ve diğerleri (1985)'a göre matematiksel düşünme, matematiksel süreçle geliştirilebilir. $\mathrm{Bu}$ gelişim; sorularla mücadele etmek, deneyimleri derinlemesine düşünmek, problemleri çözümleme süreci üzerine çalışmak ve neyi, nasıl öğreneceğini fark etmek gibi yollarla tüm yaşlardaki bireylerde gerçekleştirilebilir.

Schoenfeld (1992), matematiksel düşünmenin temel bileşenlerini; zihinde var olan bilgi, problem çözme stratejileri, bilişsel yapıların kullanımı, matematiksel bir bakış açısı, matematiksel etkinliklere katılma olarak belirtmiştir.

Tall (2004) matematiksel düşünmeye ilişkin, her biri kendi içerisinde farklı bir gelişim gösteren ama birbiriyle bağlantılı üç farklı düşünce dünyasından söz etmektedir (Akt. Coşkun, 2012: 7). Bu düşünme biçimleri bütünleştirme, sembolleştirme, mantığa uygun hale getirmedir (Tall, 2005; Akt. Coşkun 2012).

Matematiksel düşünme tanımlanırken onun bazı elemanlarından bahsedilmiştir. Mason ve diğerleri (1985), matematiksel düşünmenin özelleştirme, genelleme, varsayımda bulunma ve doğrulama - ikna etme süreçlerinden oluştuğunu, Tall (2002) ise soyutlama, sentezleme, genelleme, modelleme ve ispat ögelerinden oluştuğunu, Liu (2003) da tahmin edebilme, tümevarım, tümdengelim, betimleme, genelleme, örnekleme, biçimsel usa vurma, biçimsel olmayan usa vurma ve doğrulama süreçleriyle ortaya çıktığını belirtmiştir. Ayrıca Alkan ve Bukova - Güzel (2005) de; bireyin matematiğe ait önceki bilgilerini kullanıp soyutlama, tahminde bulunabilme, genelleme yapabilme, hipotez kurarak test edebilme, muhakeme ederek ispatlama ve sentez yapabilme vb. süreçlerle matematiksel düşüncenin meydana geldiğini belirtmişlerdir. Aşağıda matematiksel düşünmenin işleyiş yapısı verilmiştir. 


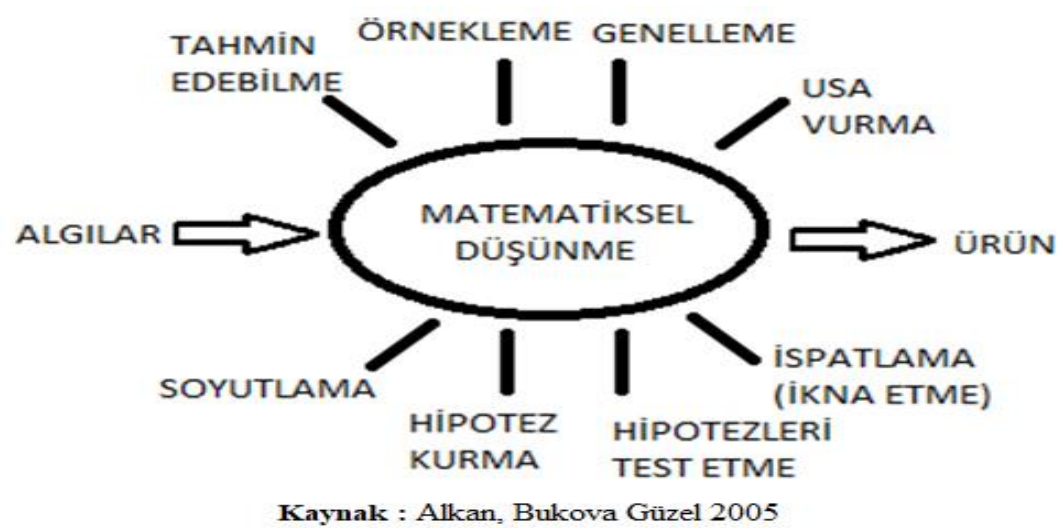

Şekil 1. Matematiksel Düşünmenin İ̧sleyiş̧ Yapısı

Matematiksel düşünmeyi oluşturan bileşenlerin bir çalışmada incelenebilmesi zor olacağından ve araştırmacıların tanımladıkları matematiksel düşünme aşamalarının birbiri içinde yer alıp bir kısmının eş anlamlı kullanılması sebebiyle, yukarıdaki bilgiler ile şekil 1 1şığında matematiksel düşünmenin özelleştirme, genelleme, varsayımda bulunma, ikna etme (doğrulama, usa vurma, ispatlama) aşamaları araştırma kapsamına alınmıştır. Bu seçim, diğer bileşenlerin reddedildiği anlamına gelmez.

\section{Özelleştirme}

Özelleştirme, bir genellemeye ulaşmayı sağlayacak kanıtları bir araya getirme işlemidir (Mason ve Ark., 1985). Polya (1957) ise özelleştirmeyi; kavramlardan oluşan bir kümeden daha küçük bir kümeye geçiş olarak tanımlar ve problemlerin çözümünde özelleştirmenin yararlı olacağını ifade eder. Özelleştirme; soruyu anlamaya, sorunun gerçekte neyle ilgili olduğunu sezmeye yardımcı olan ve soruyu çözmeye olanak sağlayan bir süreçtir. "Niçin?” sorusu üzerine yoğunlaşır (Mason, ve Ark.,1985).

Özelleştirmede; örnek verme, örneği tanımlama, anlatma, gösterme, seçme, çizme veya bulma gibi eylemler mevcuttur. Verilen herhangi bir durum için ilgili veya karşıt örnek bulma, istenilenleri doğru bularak sonucu farklı şekillerde yazma gibi eylemler de yapılabilir (Arslan ve Yıldız, 2010).

\section{Genelleme}

Genelleme, birkaç örnekten hareketle daha geniş olaylar kümesi hakkında tahminlerde bulunma şeklinde tanımlamıştır (Mason vd., 1985; Tall, 2002). Genelleme yapma, öğrencilerin matematiksel düşünme ve problem çözme yoluyla elde ettiği sonuçları birkaç örnekten yola çıkarak daha genel ve daha geniş uygulanabilir olarak yeniden ifade edilmesi ve genişletilmesi olarak tanımlanır (Mason vd., 1985; TIMMS, 2003). Dolayısıyla genelleme, matematik için hayati bir öneme sahiptir (Mason vd., 1985). Benzer şekilde genelleme, matematiksel etkinliklerin merkezi ve matematiksel bilgi gelişiminin temeli olduğu ifade edilmiştir (Polya, 1957: Akt. Amit ve Neria, 2008).

Öğrencilerin genelleme yapmalarını sağlayacak bazı stratejileri ilişkileri belirleme, varsayımları test etmek için örnekler oluşturma, fazla sayıda ve farklılıkta örnekler toplama, organize etme, aynı sonuca ulaşılan denemeleri belirleme ve benzer bir deneme yapma, iki değişken arasındaki ilişkiyi matematiksel veya sözel olarak ifade etme, varsayımlar ortaya koymadır (Bell, 1976; Akt. Pilten, 2008). Matematiksel genellemelerde belli sayıdaki adımlardan yola çıkılarak iddialar hakkında karar verilmeye çalış1ır ve bazen genellemeye ulaşmak iki üç adımda olabilirken, bazen ise sonlu sayıdaki adımların denenmesi genelleme yapmak için yeterli olmayabilir (Baki, 2006). Bu durum ise genelleme sırasında özelleştirme işleminin de yapıldığını gösterir (Arslan ve Yıldız, 2010). 
Genelleme ve özelleştirme süreçleri aşağıdaki şekil ile verilmiştir.

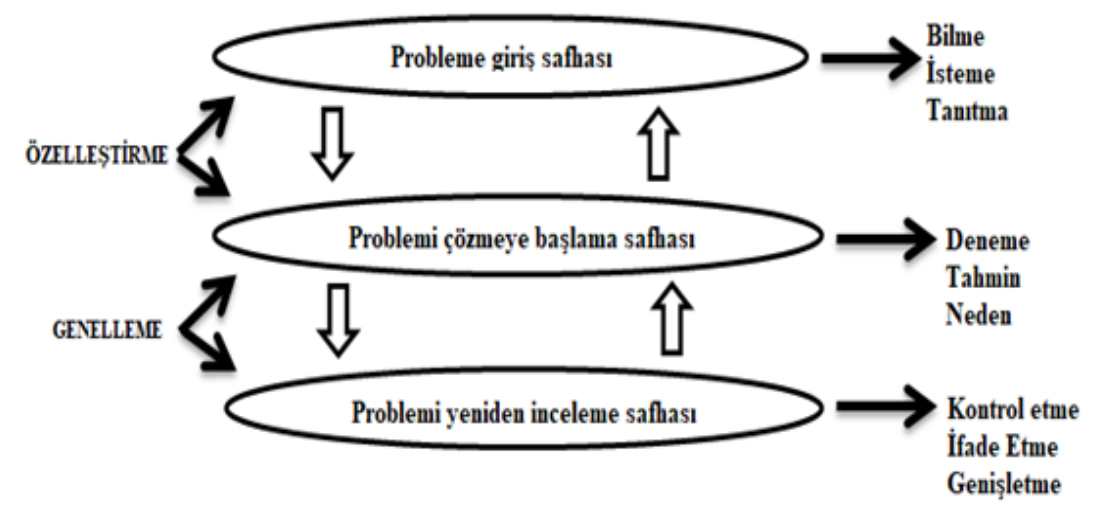

Kaynak: Hacısalihoğlu ve Ark. 2003; Stacey ve Ark. 1985; Akt. Arslan ve Yildız, 2010

Şekil 2. Özelleştirme ve Genelleme Süreçleri

\section{Varsayımda Bulunma}

Özelleştirme ve genelleme süreçlerinde kendiliğinden ortaya çıkan varsayımda bulunma ise, bir önermenin doğru olabileceğini tahmin ederek doğruluğunu araştırma sürecidir. Varsayımda bulunma sürecinde; sözel veya matematiksel olarak tahminde bulunma, matematiksel iddiaları formüle etme, önermelerden sonuç çıkarma, hipotez kurma ve test etme gibi eylemler söz konusudur (Arslan ve Yıldız, 2010). Matematiksel düşünmenin temeli; varsayımları ifade ve test etmekle gerektiğinde değiştirmek biçimde döngüsel bir süreçle aşağıdaki şekille ifade edilebilir (Mason vd., 1985; Akt. Arslan ve Yıldız, 2010).

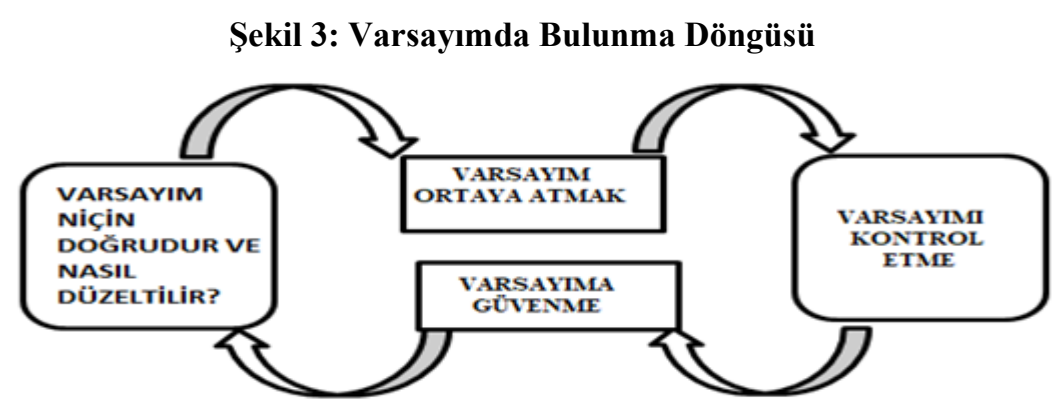

Kaynak: Stacey ve Ark. 1985; Akt. Arslan ve Yildı, 2010

\section{Şekil 3. Varsayımda Bulunma Döngüsü}

\section{İkna Etme (Usa Vurma, Doğrulama, İspatlama)}

İkna etme, usa vurma ve doğrulama bileşeni, savunulan ifadenin nedenlerini araştırma ve varsayımın doğruluğunun nedenlerini anlamaya dayalıdır (Mason vd., 1985). TDK (2019)'a göre doğrulama; Bir varsayımın doğruluğunu denetlemek için deney ve mantıksal tanıtlama yoluyla yapılan işlemlerin bütünüdür. İspat ise; tanıt ve kanıt göstererek bir şeyin gerçek yönünü ortaya çıkarma, kanıtlama, tanıtlamadır (TDK, 2019). Matematiksel düşünmenin bir bileşeni olarak ispat, önermelerin ilişkisine dayanan mantıksal bir çıkarımın doğruluğunu kanıt göstererek kabul ettirme çabasıdır (Yıldırım, 2008).

İspatlama sırasında: bir önermeyi açıklama, doğru veya yanlış olduğunu söyleme ve değişik mantıksal düşünme yollarını (tümevarımsal ve tümdengelimsel düşünme) ve ispat çeşitlerini seçme ve 
kullanma gibi eylemler söz konusudur. Şekil 4'te görüldüğü gibi matematiksel ispatlar doğrulama, açıklama ve soyutlama olmak üzere üç aşamada tamamlanır (Baki, 2008)

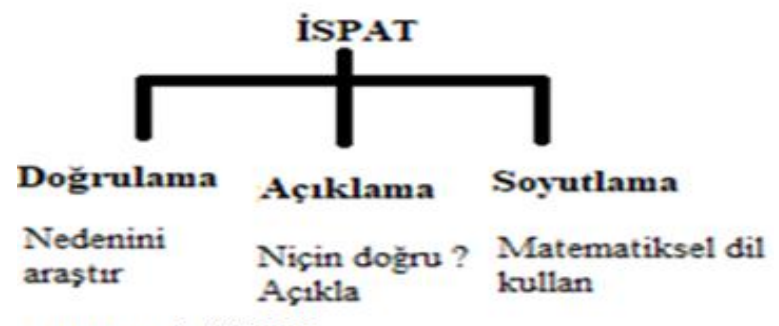

Kaynak: Baki, 2008

Şekil 4. İspat Süreci

\section{Matematik Öz Yeterlik}

Bandura (1986) tarafından öz yeterlilik; "insanların belirli performansları yapabilmesi için gerekli faaliyetleri organize edebilme ve uygulayabilme açısından kendi kapasiteleriyle ilgili ön görüşleri” olarak tanımlanmıştır.

Bireylerin problemi çözme etkinliklerini başarıyla yürütebilmeleri, kendi kendisini yönlendiren, kendini motive eden, yaşam boyu öğrenebilen bireyler haline gelebilmeleri için bilgi becerileri konusunda pozitif öz yeterlik algısı geliştirmeleri gerekmektedir (Akkoyunlu ve Kurbanoğlu 2003: 3).

Öz yeterlik algısı kişilerin matematik başarılarının da önemli bir belirleyicisidir (Pajares, 2002; Schunk ve Pajares, 2002). Pajares ve Miller (1994) yapmış olduğu çalışmada; öz yeterlik algısının matematik başarısını olumlu yönde etkilediğini, bu etkinin diğer değişkenlerin matematik başarısı üzerindeki etkilerinden daha fazla olduğunu tespit etmiştir. Yine pek çok araştırmaya göre öz yeterlik algıs1; akademik güdülenmeyi, öz düzenleme becerilerini, öğrenmeyi ve başarıyı etkilemektedir (Schunk ve Pajares, 2002; Pajares, 2002; Bandura, 1993; Schunk, 2009).

\section{Araştırmanın Amacı ve Önemi}

Matematiksel düşünme ve problem çözerken matematiksel düşünmeyi kullanma becerisi, eğitim sisteminin önemli hedeflerinden biridir (Stacey, 2006). Alan yazın incelendiğinde matematiksel düşünme süreçleri, aşamaları ve gücü ile ilgili yapılan çalışmalar son yıllarda artış göstermekle birlikte yeterli sayıda değildir ve çalışmalar ortaokul, lise öğrencileri ve öğretmen adayları üzerinde yoğunlaşmaktadır (Arslan \& Y1ldız, 2010; Keskin \& Akbaba Dağ \& Altun, 2013; Mubark, 2005; Y1ldırım, 2015; Göl, 2017; Yeşildere, 2006; Yeşildere \& Türnüklü, 2007; Karakoca, 2011; Coşkun, 2012, Uğurel \& Moral1, 2010; Alkan \& Bukova Güzel, 2005; Yağdıran, 2018; Kükey, 2018; Tuncay, 2015). Matematiksel düşünme aşmalarında ilerledikçe tüm gruplarda genel olarak zorlanıldığı ve üst aşamalara çok az kişinin çıkabildiği ortak kanaattir. Yapılan çalışmaların artış göstermesi ve öğretim programında bu beceriye ilişkin yapılan vurgu bu çalışmanın önemini artırmaktadır.

Alan yazında öz yeterlik algısı ve inancına yönelik şimdiye kadar pek çok araştırma yapılmıştır (Junge \& Beverly, 1995; Pajares \& Miller, 1994; Cantürk \& Günhan \& Pirgayipoğlu, 2004; Işıksal \& Aşkar, 2003; Şall1, 2012; Taşdemir, 2012; Reçber, 2011; Ural, 2007; Adal, 2017; Tella, 2011; Terzi \& Mirasyedioğlu, 2009; Öztürk, 2017; Ünlü \& Ertekin, 2018; Erden \& Baykal, 2008; Yaman \& Dede, 2006; Walsh, 2008). Bu araştırmaların genellikle; öğrencilerin öz yeterlik inançlarının akademik başarıları ve performansları üzerindeki etkileri, öğretmen adaylarının veya öğretmenlerin öğretimlerine/öğrenmelerine yönelik öz yeterlik inançları ve çeşitli değişkenlerin bunlar üzerindeki etkileri, cinsiyet ve sınıf düzeyi gibi alanlar üzerinde yoğunlaştığı görülmektedir (Dede, 2008; Akt. Şenay 2014). 
Tüm bu bilgiler 1şığında matematiksel düşünme aşamalarını ve matematik öz yeterlik düzeyleri aralarındaki ilişkiyi inceleyen çalışmaya rastlanmamıştır. Bu çerçevede araştırmanın amacı ortaokul 6, 7 ve 8. sınıf öğrencilerinin matematiksel düşünme aşamalarını ve matematik öz yeterlik düzeylerini belirleyerek aralarında bir ilişki olup olmadığını tespit etmek ve matematik dersi dönem sonu puanı değişkenine göre incelemektir. Bu amaçla aşağıdaki sorulara da cevap aranmıştır;

1. Araştırmaya katılan ortaokul öğrencilerinin; matematik dersi önceki dönem sonu puanı, matematik öz yeterlik düzeyleri ve matematiksel düşünme aşamaları dağılımı nasıldır?

2. Öğrencilerin matematik dersi güz dönemi sonu puanları ile matematik öz yeterlik puanları arasında anlamlı bir ilişki var mıdır?

3. Öğrencilerin matematik dersi güz dönemi sonu puanları ile matematiksel düşünme aşamaları puanları arasında anlamlı bir ilişki var mıdır?

\section{Sinırlılıklar}

$\mathrm{Bu}$ araştırma; 2017-2018 eğitim-öğretim yılında İstanbul ili Pendik ilçesindeki bir ortaokulda öğrenim görmekte olan ve çalışmaya katılan 6,7 ve 8 . sınıf öğrencileri ile sınırlıdır. Uygulamaların sınıf düzeyine ve matematiksel düşünme aşamalarına uygun oldukları belirlenerek araştırma kapsamına alınan problemler ve araştırma kapsamında uygulanan ölçek ve formlar ile sınırlıdır.

\section{YÖNTEM}

\section{Araştırma Modeli}

$\mathrm{Bu}$ araştırma ile ortaokul öğrencilerinin Matematiksel Düşünme Aşamaları ile Matematik Öz Yeterlikleri arasındaki ilişki incelenerek; öğrenim görmekte oldukları sınıf ve matematik dersi güz dönem sonu puanı açısından anlamlılı̆ga bakılmıştır. Çalışmada, nicel araştırma yöntemlerinden ilişkisel tarama modeli kullanılmıştır. İlişkisel araştırma, iki ya da daha çok değişken arasındaki ilişkinin herhangi bir şekilde bu değişkenlere müdahale edilmeden incelendiği araştırmalardır. Tarama modelinde araştırmaya konu olan birey, olay ve nesne kendi koşulları içinde ve olduğu gibi tanımlanmaya çalışılır (Karasar, 2003)". Korelasyon türü ilişkisel modelde değişkenlerin birlikte değişip değişmediği, var olan değişimin nasıl olduğu incelenir ve değişkenlerin birlikte değişimlerinin incelenmesi sonucunda neden-sonuç ilişkisi olabileceği konusunda araştırmacıya fikir verebilir, ancak bu ilişkinin kurulmasını sağlamaz (Büyüköztürk, Kılıç Çakmak, Akgün, Karadeniz, ve Demirel, 2017: 191-192).

\section{Çalışma Grubu}

Araştırmanın çalışma grubunu, 2017-2018 öğretim yılında bir devlet okulunda öğrenim gören 6, 7 ve 8. sınıflardan toplam 415 öğrenci oluşturmaktadır. Ancak kayıp veri sebebiyle (bazı çalışma yapraklarında soruların boş bırakılması), 27 öğrencinin çalışma yaprakları araştırmadan çıkarılmış ve 388 öğrenci (sırasıyla 97, 128, 163 öğrenci olmak üzere) ile araştırmaya devam edilmiştir.

Çalışmaya katılan öğrenciler, seçkisiz örnekleme yöntemlerinden basit seçkisiz örnekleme yöntemiyle seçilmiştir. Bu örnekleme yönteminde tüm bireylerin seçilme olasılığı aynıdır. Her bir bireyin seçimi, diğerinin seçimini etkilememektedir (Büyüköztürk ve Ark., 2017).

\section{Veri Toplama Araçları ve Geçerlilik Güvenirlik Çalışmaları}

Çalışmada; öğrencilere sınıf, 2017-2018 eğitim-öğretim yılı güz dönemi matematik dersi dönem sonu puanı (MDDSP) verileri için kişisel bilgiler envanteri dağıtılmıştır. 


\section{Matematik $\ddot{O}_{z}$ Yeterlik Düzeyinin Belirlenmesi}

Öğrencilerin matematik öz yeterlik düzeylerini belirlemede, Umay (2001) tarafindan geliştirilen "Matematik Öz Yeterlik Algı Ölçeği”" kullanılmıştır. Ölçek; 8 tanesi olumlu, 6 tanesi olumsuz ifade içeren beşli likert tipindedir (Ölçekteki olumsuz maddelerin ters kodlaması yapılmıştır). Bu ölçekten alınabilecek öz yeterlilik puanı; en yüksek 70 , en düşük 14'tür. Alınacak yüksek puan matematik öz yeterlik algısının yüksek olduğunu, düşük puan ise matematik öz yeterlik algısının düşük olduğunu ifade etmektedir. Ölçeğin Cronbach Alfa güvenirlik katsayısı $(\alpha)$ 0,88 olarak hesaplanmıştır. Ölçeğin güvenirlik analizi, araştırmacı tarafından tekrar yapılımış ve 0,855 olarak hesaplanmıştır.

Her öğrencinin ölçekten aldığ 1 toplam puan hesaplandığında, öğrencilerin en az 14 puan ve en çok 70 puan aldığı tespit edilmiştir. Daha sonra alınan en yüksek puan ile en düşük puan çıkarılıp üçe (üç düzey) bölünmüş ve buna göre 14-32 arası düşük düzey, 33-51 arası orta düzey, 52-70 aras1 yüksek düzey olarak belirlenmiş olup öğrenciler bu düzeylere atanmıştır.

\section{Matematiksel Düşünme Aşamalarının (MDA) Belirlenmesi}

Öğrencilerin matematiksel düşünme aşamalarını belirlemek için 4 alt boyuttan (özelleştirme, genelleme, varsayımda bulunma ve ikna etme/usa vurma/ispatlama) oluşan ve 3 farklı çalışma yaprağı içeren "Matematiksel Düşünme Aşamaları Belirleme Ölçeği” kullanılmıştır. Çalışma yapraklarından ikisi araştırmacı tarafından geliştirilmiştir. Biri ise Keskin, Akbaba Dağ ve Altun (2013)'a aittir. Çalışma yapraklarındaki sorular matematiksel düşünmenin aşamalarındaki davranışları ortaya koyabilecek nitelikte düzenlenmiştir. Çalışma yapraklarındaki 1. sorular özelleştirme (özel değerleri için durumu test etme), 2. sorular genelleme, 3.sorular varsayımda bulunma ve 4.sorular ise usa vurma/ikna etme/ispatlama ile ilişkilidir. Araştırmacı tarafından geliştirilen soruların bu aşamalara yönelik olduğu kanaatine, matematik eğitiminde uzman 3 akademisyenin görüşleri alınarak karar kılınmıştır. Daha sonra araştırmaya katılmayan 5 öğrenci ile pilot çalışma yapılmış ve çalışma yaprakları son haline getirilmiştir.

“Matematiksel Düşünme Aşamaları Belirleme Ölçeği”ndeki her bir çalışma yaprağı, aşağıdaki dereceli puanlama anahtarları kullanılarak puanlanmıştır.

Tablo 1. Özelleştirme Aşamasina Ait Dereceli Puanlama Anahtarı

\begin{tabular}{c|cl}
\hline \multirow{2}{*}{0 puan } & $\bullet$ & Boş birakma \\
& $\bullet$ & $\begin{array}{l}\text { Soru ile ilişkisiz (rastgele) cevaplar verme } \\
\text { Yanlış cevaplar verme }\end{array}$ \\
\hline 1 puan & $\bullet$ & Kismen doğru cevaplar verme \\
\hline 2 puan & $\bullet$ & Tamamen doğru cevaplar verme, tabloyu doğru şekilde tamamlama \\
\hline
\end{tabular}

Tablo 2. Genelleme Aşamasına Ait Dereceli Puanlama Anahtarı

\begin{tabular}{|c|c|}
\hline 0 puan & $\begin{array}{ll}\text { - } & \text { Boş bırakma } \\
\text { - } & \text { Soru ile ilişkisiz (rastgele) cevaplar verme } \\
\text { - } & \text { Örüntüyü keşfedememe }\end{array}$ \\
\hline 1 puan & $\begin{array}{l}\text { • Örüntüyü keşfetmiş ancak devamında yeterli açıklamalar yapamamış } \\
\text { • Bir örüntü oluşturup özelleştirmede doğru sonuca ulaşmış fakat istenen ve beklenen } \\
\text { örüntü ifade edilememiş }\end{array}$ \\
\hline 2 puan & - $\quad$ Örüntüyü keşfetmiş, sözel ve/veya matematiksel olarak doğru şekilde ifade etmiş \\
\hline
\end{tabular}


Tablo 3. Varsayımda Bulunma Aşamasına Ait Dereceli Puanlama Anahtarı

\begin{tabular}{l|l}
\hline 0 puan & $\begin{array}{l}\text { - Boş bırakma } \\
\text { S Soru ile ilişkisiz (rastgele) cevaplar verme } \\
\text { Y Yanlış cevaplar verme }\end{array}$ \\
\hline 1 puan & $\begin{array}{l}\text { • Sözel ve/veya matematiksel olarak istenen ve beklenen olmayan bir varsayımda bulunup, } \\
\text { doğru ya da kısmen doğru sonuca ulaşmış }\end{array}$ \\
\hline 2 puan & $\bullet \quad$ Sözel ve/veya matematiksel olarak doğru varsayımda bulunup, doğru sonuca ulaşmış \\
\hline
\end{tabular}

Tablo 4. İkna Etme (Usa Vurma, İspatlama) Aşamasına Ait Dereceli Puanlama Anahtarı

\begin{tabular}{|c|c|}
\hline 0 puan & $\begin{array}{l}\text { - Boş bırakma } \\
\text { - Soru ile ilişkisiz (rastgele) cevaplar verme } \\
\text { - Yanlış cevaplar verme }\end{array}$ \\
\hline 1 puan & $\begin{array}{l}\text { - Formülü (matematiksel ifadeyi) doğru şekilde yazmış ikna / ispat yapmamış, yanlış } \\
\text { şekilde ikna etmeye/ispat yapmaya çalışmış, kısmen doğru ikna etme / ispatlama yapmış }\end{array}$ \\
\hline 2 puan & $\begin{array}{l}\text { - Formülü (matematiksel ifadeyi) doğru şekilde yazıp değişkene değer vererek } \\
\text { aritmetiksel olarak ikna etme/ispatlama yapmış }\end{array}$ \\
\hline
\end{tabular}

Yukarıdaki düzenleme yapılırken aşağıda belirtildiği gibi hareket edilmiştir:

Öğrencilerin matematiksel düşünme aşamalarının hangisinde oldukları tespit edilirken ilk olarak 3 çalışma yaprağındaki ilgili düzeye ait sorulardan alınabilecek puanın en az $2 / 3$ sini almış olma şartı aranmıştır. Daha sonra ise, matematiksel düşünme aşamalarının çalışmada alınan kısmının sıralı bir yapıya sahip olduğu göz önüne alınarak öğrencinin bir aşamaya atanabilmesi için daha önceki aşamalarda başarılı olma koşulu aranmıştır.

\section{Verilerin Toplanması}

Veri toplama araçlarını geliştiren ve/veya uyarlayan kişilerle mail ortamı üzerinden iletişime geçilip izin alındıktan sonra veri toplama araçları hazırlanmıştır. Araştırma İstanbul ili Pendik ilçesindeki bir devlet okulunda yapılmıştır. Gerekli izinler İstanbul İl Milli Eğitim Müdürlügü’nden, okul yönetiminden ve velilerden alınmıştır. Sonrasında, uygulamanın yapılacağı ders öğretmenleri ile görüşülüp, işbirliği yapılarak, araştırmacının kontrolünde "Matematik Öz Yeterlik Ölçeği (Ek-2)" ile "Matematiksel Düşünme Aşamaları Belirleme Ölçekleri (Ek-3)", 2017-2018 eğitim-öğretim yılı bahar dönemi Haziran ayında uygulanmıştır. Araştırmaya katılan öğrencilerin, "Matematik Öz Yeterlik Ölçeği”" ve "Kişisel Bilgiler Envanterini" tamamlamaları ortalama 20 dakika sürmüştür. İkinci aşama olan "Matematiksel Düşünme Aşamaları Belirleme Ölçeği" çalışma yapraklarını cevaplamaları ise yaklaşık 75-80 dakika sürmüştür.

\section{Verilerin Analizi}

Uygulama sonucunda elde edilen veriler SPSS 22.0 paket programı kullanılarak analiz edilmiştir. Pearson Ki-Kare Testi ve Spearman Sıra Farkları Korelasyon katsayısı tekniği kullanılıp, karşılaştırmalarda anlamlılık (p) 0,05 düzeyinde test edilmiştir.

Karşılaştırılan gruplar arasında farkın anlamlı çıkması durumunda etki büyüklüğü (effect size) değerine bakılmıştır. Ki kare testlerinde elde edilen etki büyüklüğü için Cramer'sV değerinin serbestlik derecesi dikkate alınarak yorum yapılmıştır. 
$\mathrm{Bu}$ araştırma kapsamında kullanılan Matematik Öz Yeterlik Ölçeği ve Matematiksel Düşünme Aşamalarını Belirleme Ölçeği'nden elde edilen veriler için araştırma problemi ve alt problemlerindeki sorulara cevap aranırken tablo 5' teki analizler uygulanmıştır.

Tablo 5. Araştırmadaki Değişkenler ile Yapılan Analizler

\begin{tabular}{ll}
\hline Değişkenler & Yapılan Analizler \\
\hline MDDSP, MÖYD ve MDA & \% (yüzde) - f (frekans) \\
\hline MÖYD ile MDA & Pearson ki kare (Chi- Square) Testi \\
\hline MÖY Puanları ile MDDSP & Spearman Sıra Farkları \\
MDA puanları ile MDDSP & Korelasyon Katsayısı \\
MÖY Puanları ile MDA Puanları & \\
\hline MDA $\quad:$ Matematiksel Düşünme Aşamaları & \\
MDDSP & $:$ Matematik Dersi Dönem Sonu Puanı (Güz Dönemi) \\
MÖY & $:$ Matematik Öz Yeterlik \\
MÖYD & $:$ Matematik Öz Yeterlik Düzeyleri \\
\hline
\end{tabular}

\section{BULGULAR VE YORUMLAR}

Bu bölümde, araştırmaya katılan 6, 7 ve 8. sınıf öğrencilerinin Matematiksel Düşünme Aşamaları İle Matematik Öz Yeterlikleri arasındaki ilişkilerin ve farklılıkların incelenmesi amacıyla gerçekleştirilen veri toplama ve toplanan verilerin istatistiksel analizleri sonucunda ulaşılan bulgulara ve bu bulgulara ilişkin yorumlara yer verilmiştir.

Öncelikle Matematik Öz Yeterlik Düzeyleri (MÖYD) ve Matematiksel Düşünme Aşamaları (MDA) ölçekleri sonuçlarının normallik analizleri yapılmış ve eldeki veriler normal dağılım göstermedikleri için parametrik analizler yapılamamış ve parametrik olmayan analizler kullanılmıştır.

\section{Birinci Alt Probleme Ait Bulgular ve Yorumlar}

Araştırmanın ilk problemi olan "Araştırmaya katılan ortaokul öğrencilerinin Matematik Dersi Güz Dönem Sonu Puanı (MDDSP), Matematik Öz Yeterlik Düzeyleri (MÖYD) ve Matematiksel Düşünme Aşamaları (MDA) dağılımı nasıldır?" sorusu aşağıdaki tablolarda frekans ve yüzde değerleri biçiminde özetlenmiştir.

Tablo 6. Öğrencilerin Matematik Dersi Puanlarına (MDDSP) İlişkin Frekans ve Yüzde Değerlerinin Dağılımı

\begin{tabular}{ccc}
\hline Puanlar & f & \% \\
\hline $1(0-44)$ & 4 & 1,0 \\
$2(45-54)$ & 24 & 6,2 \\
$3(55-69)$ & 76 & 19,6 \\
$4(70-84)$ & 94 & 24,2 \\
$5(85-100)$ & 190 & 49,0 \\
Toplam & 388 & 100,0 \\
\hline
\end{tabular}


Tablo 6' ya göre öğrencilerin matematik dersi güz dönemi sonu puanları incelendiğinde; öğrenci kitlesinin yaklaşık yarısının 84-100 puan, çok azının 0-44 puan aralığında olduğu görülmektedir.

Tablo 7. Öğrencilerin Matematik Öz Yeterlik Düzeyine (MÖYD) İlişkin Frekans ve Yüzde Değerlerinin Dă̆ılımı

\begin{tabular}{lcc}
\multicolumn{1}{c}{ MÖYD } & f & \% \\
\hline 14-32 (Düşük) & 19 & 4,9 \\
33-51 (Orta) & 215 & 55,4 \\
52-70 (Yüksek) & 154 & 39,7 \\
Toplam & 388 & 100,0 \\
\hline
\end{tabular}

Tablo 7 de öğrencilerin büyük çoğunluğunun matematik öz yeterlik düzeylerinin orta ve yüksek olduğu görülmektedir.

Tablo 8. Öğrencilerin Matematiksel Düşünme Aşamalarına (MDA) İlişkin Frekans ve Yüzde Dĕgerlerinin Dă̆ılımı

\begin{tabular}{lcc}
\hline MDA & f & \% \\
\hline 1 (Özelleştirme) & 169 & 43,6 \\
2 (Genelleme) & 138 & 35,6 \\
3 (Varsayımda Bulunma) & 48 & 12,4 \\
4(İknaetme/usavurma/ispatlama) & 33 & 8,5 \\
Toplam & 388 & 100,0 \\
\hline
\end{tabular}

Tablo 8' e göre öğrencilerin büyük çoğunluğunun özelleştirme aşamasında olduğu, ikna etme aşamasına doğru sayının oldukça azaldığı görülmektedir.

\section{İkinci Alt Probleme Ait Bulgular ve Yorumlar}

Araştırmanın ikinci alt problemini "Öğrencilerin matematik dersi güz dönemi sonu puanları ile matematik öz yeterlik puanları arasında anlamlı bir ilişki var mıdır?” sorusu oluşturmaktadır. Bu alt probleme ilişkin bulgulara Spearman Sıra Farkları Korelasyon Testi ile ulaşılmıştır.

Tablo 9. Matematik Dersi Dönem Sonu Puanları (MDDSP) İle Matematik Öz Yeterlik (MÖY) Puanları Arasındaki İlişki Sonuçları

\begin{tabular}{lcc}
\hline & MDDSP & MÖY Puanı \\
MDDSP & 1 & \\
MÖY Puanı &, $561^{* *}$ & 1 \\
\hline & & \\
& &
\end{tabular}

Tablo 9' dan anlaşılacağı gibi öğrencilerin Matematik Öz Yeterlik (MÖY) ölçeğinden aldıkları puanlar ile Matematik Dersi Dönem Sonu Puanları (MDDSP) arasındaki Spearman Sıra Farkları korelasyon analizi sonrasında öğrencilerin MÖY'si ile MDDSP'si arasında pozitif yönde orta düzeyde anlamlı bir ilişki olduğu görülmüştür $\left(r_{388}=.561, \mathrm{p}<.05\right)$. Diğer bir ifade ile öğrencilerin matematik dersi dönem sonu puanları artma eğilimindeyken matematik öz yeterlik puanları da artma eğilimindedir. 


\section{Üçüncü Alt Probleme Ait Bulgular ve Yorumlar}

Araştırmanın üçüncü alt problemini "Öğrencilerin matematik dersi güz dönemi sonu puanları ile matematiksel düşünme aşamaları puanları arasında anlamlı bir ilişki var mıdır?" sorusu oluşturmaktadır. $\mathrm{Bu}$ alt probleme ilişkin bulgulara Spearman Sıra Farkları Korelasyon Testi ile ulaşılmıştır.

Tablo 10. Matematik Dersi Dönem Sonu Puanları İle Matematiksel Düşünme Aşamaları Puanları Arasındaki İlişki Sonuçları

\section{MDDSP}

MDA Puanı

MDDSP

\section{1}

MDA Puanı

, $563^{* *}$

1

$* * \mathrm{p}<.01$

Tablo 10' a bakıldığında, öğrencilerin Matematiksel Düşünme Aşamaları ölçeğinden aldıkları puanlar ile Matematik Dersi Dönem Sonu Puanları (MDDSP) arasında yapılan Spearman Sira Farkları korelasyon analizi sonrasında öğrencilerin MDA ile MDDSP si arasında pozitif yönde orta düzeyde anlamlı bir ilişki olduğu görülmüştür $\left(r_{388}=.563, \mathrm{p}<.05\right)$. Diğer bir ifade ile öğrencilerin matematik dersi dönem sonu puanları artma eğilimindeyken matematiksel düşünme aşamaları puanları da artma eğilimindedir.

Ayrıca matematiksel düşünme aşamalarının her biri ile MDDSP değerleri arasında Spearman Sıra Farkları analizi yapıldığında şu sonuçlara ulaşılmıştır:

Tablo 11. Matematik Dersi Dönem Sonu Puanı (MDDSP) ile Matematiksel Düşünme Aşamaları (MDA) Puanı İliş̧ki Sonuçları

\begin{tabular}{|c|c|c|c|c|c|}
\hline Değişkenler & MDDSP & Özelleştirme & Genelleme & $\begin{array}{c}\text { Varsayımda } \\
\text { Bulunma }\end{array}$ & $\begin{array}{c}\text { İkna Etme/ } \\
\text { İspatlama }\end{array}$ \\
\hline MDDSP & 1 & & & & \\
\hline Özelleştirme &, $287^{* *}$ & 1 & & & \\
\hline Genelleme &, $538^{* *}$ &, $453^{* *}$ & 1 & & \\
\hline $\begin{array}{l}\text { Varsayımda } \\
\text { Bulunma }\end{array}$ &, $521^{* *}$ &, $379^{* *}$ &, $775^{* *}$ & 1 & \\
\hline $\begin{array}{l}\text { İkna Etme/ } \\
\text { İspatlama }\end{array}$ &, $496^{* *}$ &, $327^{* *}$ &, $646^{* *}$ &, $729^{* * *}$ & 1 \\
\hline$* * p<.01$ & & & & & \\
\hline
\end{tabular}

Tablo 11'de Matematik Dersi Dönem Sonu Puanları (MDDSP) ile Matematiksel Düşünme Aşamalarından (MDA) her birinin puanları arasında Spearman Sıra Farkları korelasyon analizi sonucunda MDDSP ile özelleştirme arasında pozitif yönlü zayıf düzeyde bir ilişki $(\mathrm{r}=.0287, \mathrm{p}<.05)$ bulunmuştur. MDDSP ile genelleme arasinda $(\mathrm{r}=.538, \mathrm{p}<.05)$, MDDSP ile varsayımda bulunma arasinda $(\mathrm{r}=.521$, $\mathrm{p}<.05$ ), MDDSP ile ikna etme (usa vurma, ispatlama) arasında $(\mathrm{r}=.496, \mathrm{p}<.05)$ ise pozitif yönlü orta düzeyde bir ilişki bulunmuştur.

Ayrıca özelleştirme ile genelleme arasında $(\mathrm{r}=.453, \mathrm{p}<.05)$, özelleştirme ile varsayımda bulunma arasında $(\mathrm{r}=.379, \mathrm{p}<.05)$, özelleştirme ile ikna etme (usa vurma, ispatlama) aşamaları arasında $(\mathrm{r}=.327$, $\mathrm{p}<.05)$ pozitif yönlü orta düzeyde bir ilişki bulunmuştur. 
Genelleme ile varsayımda bulunma aşamaları arasında pozitif yönlü yüksek düzeyde bir ilişki (r $=.775, \mathrm{p}<.05$ ), Genelleme ile ikna etme (usa vurma, ispatlama) aşamaları arasında pozitif yönlü orta düzeyde bir ilişki $(\mathrm{r}=.646, \mathrm{p}<.05)$ bulunmuştur.

Son olarak varsayımda bulunma ile ikna etme (usa vurma, ispatlama) aşamaları arasında pozitif yönlü yüksek düzeyde bir ilişki $(r=.729, \mathrm{p}<.05)$ tespit edilmiştir.

\section{Çalışmanın Araştırma Problemine Ait Bulgular ve Yorumlar}

$\mathrm{Bu}$ çalışmada; "Ortaokul öğrencilerinin matematiksel düşünme aşamaları ile matematik öz yeterlikleri arasında anlamlı bir ilişki var mıdır?” problemine ilişkin bulgular için öncelikle matematiksel düşünme aşamaları ile matematik öz yeterlik düzeyleri aralarındaki farkın anlamlılığına Pearson Ki-Kare Testi ile bakılıp yorumlanmıştır. Sonrasında aralarındaki ilişkinin tespiti için puanlar bazında Spearman Sıra Farkları korelasyon analizi yapılmıştır.

Tablo 12. Matematiksel Düşünme Aşamaları (MDA) ile Matematik Öz Yeterlik Düzeyleri (MÖYD) Anlamlılık Testi Bulguları

\begin{tabular}{ccccc}
\hline Değişkenler & $\mathbf{N}$ & $\chi^{2}$ & Sd & P \\
MDA ile MÖYD & 388 & 46,177 & 6 &, 000 \\
\hline
\end{tabular}

Tablo 12'de öğrencilerin Matematiksel Düşünme Aşamaları ile Matematik Öz Yeterlik Düzeyleri arasında anlamlı bir farlılık olup olmadığ Pearson Ki-Kare Testi ile incelenmiştir. Sonuçta; $\left(\mathrm{x}^{2}(6, \mathrm{n}=\right.$ 388)=46,177; $\mathrm{p}<0.05 ; V=0.244$ ) MDA ile MÖYD arasında anlamlı bir farklılık olduğu tespit edilmiştir. Etki büyüklügü (Cramer's $V$ ) değerine göre MDA ile MÖYD arasında yüksek bir ilişki olduğu görülmektedir.

Tablo 13. Matematiksel Düşünme Aşamaları (MDA) ile Matematik Öz Yeterlik (MÖY) Puanları Arasındaki İlişki Sonuçları

\begin{tabular}{ccc}
\hline & MDA & MÖY \\
MDA & 1 & \\
MÖY &, $377^{* *}$ & 1 \\
\hline
\end{tabular}

$* * \mathrm{p}<.01$

Tablo 13'e bakıldığında öğrencilerin MDA ölçeğinden aldıkları puanlar ile MÖY ölçeğinden aldıkları puanlar arasında yapılan Spearman Sıra Farkları korelasyon analizi sonrasında öğrencilerin matematiksel düşünme aşamaları ile matematik öz yeterlikleri arasında pozitif yönde orta düzeyde anlamlı bir ilişki olduğu görülmüştür $\left(r_{388}=.377, \mathrm{p}<.05\right)$. Diğer bir ifade ile öğrencilerin matematiksel düşünme aşamaları artma eğilimindeyken matematik öz yeterlikleri de artma eğilimindedir.

\section{Sonuçlar ve Tartışma}

$\mathrm{Bu}$ bölümde çalışmadan elde edilmiş bulgulara dayalı sonuçlar, ilgili alan yazında yapılmış çalışmalarla tartışılmıştır.

Matematiksel düşünmenin; özelleştirme, genelleme, varsayımda bulunma, ikna etme (usa vurma, doğrulama, ispatlama) aşamalarının, matematik öz yeterlik ile ilişkisi olduğu düşünülmüş ve bu çalışmanın odak noktası olarak belirlenmiştir. Ayrıca öğrencilerin matematiksel düşünme aşamaları ve matematik öz yeterlik düzeyleri; matematik dersi güz dönem sonu puanı değişkeni açısından incelenmiştir. 
Araştırmaya katılan ortaokul öğrencilerinin matematik dersi güz dönem sonu puanı (MDDSP), matematik öz yeterlik düzeyleri (MÖYD) ve matematiksel düşünme aşamaları (MDA) dağılımına frekans ve yüzdelerle bakılmıştır. MDDSP' ye bakıldığında; örneklemin yarıya yakının 85-100 puan aralığında, çeyreğe yakınının 70-84 puan aralığında olduğu ve 0-44 puan aralığında çok az öğrencinin bulunduğu görülmektedir. Bu durumda örneklemdeki öğrencilerin MDDSP' ye göre başarı düzeyi yüksek bir kitle olduğu söylenebilir.

MÖY ölçeğinden alınan puanlara göre belirlenen üç düzey için de öğrencilerin yarıdan fazlası orta düzeyde öz yeterliğe sahiptir. Bunu takiben sırayla yüksek ve düşük düzeyler gelmektedir.

Öğrencilerin matematiksel düşünme aşamalarını belirlerken yapılan incelemelerde özelleştirme aşaması ile ilgili soruların çoğu doğru cevaplanmıştır. Yani özelleştirme aşamasında pek fazla sıkıntı çekilmediği söylenebilir. Bunun sebebi okullarda matematik ve matematik uygulamaları dersleri işlenirken özel durum içeren sorulara ve işlemsel bilgiye ağırlık veriliyor olabileceğinden kaynaklanabilir. Bu sonuç Arslan ve Yıldız (2010), Mubark (2005), Keskin ve Akbaba Dağ ve Altun (2013), Göl (2017) farklı örneklemlerle yaptıkları benzer çalışmalarda öğrencilerin çoğunun özelleştirme aşamasında gerekli olan işlemleri doğru yaptıkları sonucu ile örtüşmektedir.

Genelleme, varsayımda bulunma ve ikna etme (usa vurma, doğrulama, ispatlama) aşamalarına doğru ilerledikçe bu aşamalara ulaşan öğrenci sayılarında düşüş yaşanmaktadır. Özellikle genelleme aşamasından sonra diğer iki aşamaya çıkabilen öğrenci sayısı oldukça azdır. Matematiksel düşünme aşamalarından özelleştirme aşamasında kalan öğrenci sayısında bir yığılma olmuştur. Sonra bunu sırasıyla; genelleme, varsayımda bulunma ve ikna etme (usa vurma, ispatlama) aşamaları takip etmiştir. Bu durum; Arslan ve Yıldız (2010), Keskin ve Akbaba Dağ ve Altun (2013), Mubark (2005) ile Göl (2017)'ün çalışmalarındaki matematiksel düşünmenin özelleştirme aşamasından ispatlama aşamasına doğru gidildikçe başarının düştügü sonucu ile paralellik göstermektedir. Buna ek olarak Yıldırım (2015)' 1n geometri problemlerini MD' nin özelleştirme ve genelleme aşamaları bağlamında incelediği çalışmasında, öğrencilerin özelleştirmede zorluk yaşamadıkları, genelleme aşamasında zorlanan öğrenciler olsa da çoğunluğun bu aşamaya ulaşabildiği sonucu, Yeşildere (2006)'nin matematiksel güç ile ilgili yaptığı çalışmada öğrencilerin matematiksel güçlerinin (tahmin etme, mantıksal çıkarım yapma, ilişkilendirme, akıl yürütme vb.) düşük olduğu sonucu, Yeşildere ve Türnüklü (2007)'nün MD ve akıl yürütme süreçlerini incelediği çalışmada öğrencilerin işlemsel bilgilerde pek zorluk çekmediği ancak akıl yürütmede, tahmin etmede ve ilişkilendirmede zorlandıkları sonucu ile Karakoca (2011)'nın problem çözmede MD durumlarını incelediği çalışmada öğrencilerin akıl yürütme, esnek düşünme gibi becerilerde sorun yaşadıkları sonucu, Coşkun (2012)'un öğretmen adayları ile yaptığı çalışmada üst düzey MD aşamalarından genellemede başarılı oldukları soyutlama ve sentez basamaklarına doğru başarının düştüğü sonuçları ile benzerlik göstermektedir.

Matematiksel Düşünmenin; genelleme, varsayımda bulunma, ikna etme (usa vurma, doğrulama, ispatlama) aşamalarında daha çok sözel ifadeler ve aritmetiksel işlemler tercih edilmiş ve matematiksel ifadelere daha az rastlanmaktadır. Bu sonuç Arslan ve Yıldız (2010)'ın çalışmaları ile uyumlu iken Keskin, Akbaba Dağ ve Altun (2013) ile Göl (2017)'ün 11. sinıflarda ispat yaparken daha çok matematiksel (cebirsel) ifadeler kullandıkları sonucu ile farklılaşmaktadır. Bu farklılaşmanın sebebi çalışmaların daha başarılı sınıflarla ve lise öğrencileriyle yapılmasından kaynaklanabilir.

Çalışmada ikna etme (usa vurma, doğrulama, ispatlama) aşamasına çok az öğrencinin çıkabilmiş olması, yani ikna etmede (ispatlama) oldukça zorlandıkları sonucu ile Uğurel ve Moralı (2010)'nın 11. sınıf öğrencileri yaptığı çalışma ile Alkan ve Bukova-Güzel (2005)'in öğretmen adayları ile yaptığı çalışma sonuçları ispat aşamasında büyük sıkıntı çekildiğini belirtmekte ve bu durum bu çalışma ile uyumludur. 
İkinci alt problemde; öğrencilerin matematik dersi güz dönemi sonu puanları ile matematik öz yeterlik puanları arasında anlamlı bir ilişkinin olup olmadığ 1 araştıılmıştır. MDDSP ile MÖYP arasında pozitif yönde orta düzeyde anlamlı bir ilişki bulunmuştur. Bu sonuç; matematik dersi dönem sonu puanı yüksek olan öğrencilerin aynı zamanda yüksek matematik öz yeterlik algısına sahip olabileceğini gösterebilir.

Bu durum; Pajares ve Miller (1994), Öztürk (2017), Alıcı ve Erden ve Baykal (2008), Terzi ve Mirasyedioğlu (2009) farklı örneklemlerle yaptıkları çalışmaların sonuçları ile örtüşmektedir.

Üçüncü alt problemde; öğrencilerin matematik dersi güz dönemi sonu puanları ile matematiksel düşünme aşamaları puanları arasında anlamlı bir ilişkinin olup olmadığına bakılmıştır. Öğrencilerin MDDSP ile MDA puanları arasında pozitif yönde orta düzeyde anlamlı bir ilişki olduğu görülmüştür. Öğrencilerin MDDSP arttıkça MD aşamalarındaki artışın, matematiğe çalıştıkça konulara aşina olmaları ve böylelikle varsayım, tahmin ve yorumlama gibi becerilerin gelişmesinden kaynaklı olduğu düşünülebilir. Bu sonuç Karakoca (2011)'nın problem çözmede MD durumlarında matematik başarısı değişkeninde anlamlı derecede farklılaşma görüldüğü, Alkan ve Bukova-Güzel (2005)'in çalışmasında matematik öğretmen adaylarının analiz 1 ve 2 dersleri puanları ile MD arasında doğrusal bir ilişki olduğu, Mubark (2005)'ın çalışmasında MD ile matematik başarısı arasında anlamlı bir ilişki bulunduğu, Kocaman (2017)'ın çalışmasında MD ile başarı arasında pozitif yönlü anlamlı ilişki olduğu, Nepal (2016)'ın çalışmasında MD ve Matematik Başarıları arasında güçlü bir ilişki olduğunu sonuçlarıyla uyumludur. Fakat; Alkan ve Bukova-Güzel (2005)'in çalışmasında öğretmen adaylarının ÖSS puanları ve 1. sınıf dönem ortalamaları ile MD arasında ilişki bulunamadığı sonucuyla farklılaşmaktadır.

Öğrencilerin matematiksel düşünme aşamalarının her biri ile ayrı ayrı matematik dersi dönem sonu puanları arasında ilişkinin düzeyi araştırıldığında; MDDSP ile özelleştirme arasında pozitif yönlü zayıf bir ilişki, MDDSP ile genelleme, varsayımda bulunma, ikna etme (usa vurma, doğrulama, ispatlama) aşamaları ile pozitif yönlü orta düzeyde bir ilişki bulunmuştur. Özelleştirme aşaması ile diğer matematiksel düşünme aşamaları arasında da pozitif yönlü orta düzeyde bir ilişki bulunmuş, genelleme ile varsayımda bulunma ve ikna etme (usa vurma, doğrulama, ispatlama) aşamaları arasında pozitif yönlü yüksek düzeyde bir ilişki bulunmuştur.

Son olarak çalışmanın başlığını oluşturan öğrencilerin matematiksel düşünme aşamaları ile matematik öz yeterlikleri arasındaki ilişkinin olup olmadığı araştırılmıştır. Bunun için önce öğrencilerin bulundukları matematiksel düşünme aşamaları ile matematik öz yeterlik düzeyleri arasında anlamlı bir farklılığın olup olmadığına bakılmıştır.

MDA'nın; özelleştirme aşamasında olanların büyük çoğunluğunun MÖYD' si orta, genelleme ve varsayımda bulunma aşamalarında olanların MÖYD' si orta ve yüksek düzeydedir. MDA' nın ikna etme (usa vurma, doğrulama, ispatlama) aşamasında MÖYD'si düşük öğrenci yok ve büyük çoğunluğu yüksek düzeydedir. Öğrencilerin matematiksel düşünme aşamaları ile matematik öz yeterlik düzeyleri arasında anlamlı bir farklılık bulunmuştur. Daha sonra MDA puanları ile MÖY puanları arasındaki ilişki durumu incelenmiş ve aralarında pozitif yönde orta düzeyde anlamlı bir ilişki bulunmuştur. Burada MDA' nın üst seviyelerine MÖYD’ si yüksek öğrencilerin çıktı̆̆ı sonucuna ulaşılmıştır.

\section{Öneriler}

Araştırmanın sonuçlarına göre öğrencilerin büyük çoğunluğunun matematiksel düşünme aşamalarında üst seviyelere çıkamadıkları görülmüştür. Bazı kitaplarda rutin, kapalı uçlu ve sadece dört işlem içeren sorular içerdiğinden ders planları ve öğrencilerin kullandığı ders kitapları; matematiksel düşünmenin alt boyutlarını destekleyecek biçimde düzenlenmelidir. Ayrıca öğretim programları, ders 
planları ve öğrencilerin kullandığı ders kitapları; matematiksel düşünmenin yorumlama, tahmin etme, akı1 yürütme, sentezleme vd. becerilerini içeren yapıda hazırlanması faydalı olacaktır.

Öğrencilere; arkadaşları ile birlikte matematiksel düşünmenin alt boyutlarını içeren (özellikle genelleme, varsayımda bulunma, ikna etme vb.) örneklerin olduğu öğrenme etkinliklerine, belirli noktalarda beraberce tartışmaları sağlanarak matematiksel dili daha iyi kullanabilecekleri ve Matematiksel Düşünme Aşamalarını daha iyi kavrayabilecekleri pozitif ortamlar sağlanabilir. Bu durumun matematik öz yeterliğinde ve matematik başarısında artışı sağlayacağı düşünülmektedir.

Yeni sınav sistemi olan LGS' de ders kazanımları esas alınarak anlama, yorumlama, analiz yapma, eleştirel düşünme, bilgiyi sentezleme, problem çözme vb. üst düzey beceriler ölçülmektedir. Sinavda matematiksel düşünmenin aşamalarına yönelik sorular sorulduğu için öğretmenlerin, öğrencilerini sınıf ortamında rutin olmayan problemlerle de desteklemesi gerekmektedir. Hatta dönem içerisinde kendilerinin hazırlayıp uyguladıkları sınavlarda da matematiksel düşünmenin üst aşamalarına yönelik rutin olmayan sorular sormaları öğrencilerin bu tarz sorulara aşina olup, çözmek için çaba sarf etmeleri sağlanabilir.

Sınıf ortamlarında öğrencilerin matematik öz yeterlik algılarını artıracak ve onlara matematiği sevdirecek tarzda hazırlanan rutin olmayan gündelik hayat problemleri içerecek etkinlikler hazırlanabilir. $\mathrm{Bu}$ sayede öğrencilerin kendilerinde var olan potansiyellerini ortaya çıkarmalarına yardımcı olunabilir ve öz yeterliklerinin gelişmesinde etkili olabilir.

Bundan sonra yapılacak olan çalışmalarda; öğrencilerin matematiksel düşünme aşamaları, farklı değişkenlerle (tutum, kaygı, bireysel özellik vb.) ilişkisi bakımından incelenebilir.

Matematiksel düşünmenin bu çalışmada alınan dört aşamasından farklı birçok aşaması mevcuttur. $\mathrm{Bu}$ çalışma genişletilip farklı veri toplama araçlarıyla matematiksel düşünmenin diğer aşamalarıyla birlikte yeniden yapılabilir.

Araştırmanın daha kısıtlı öğrenci grupları üzerinde klinik veya yarı yapılandırılmış mülakatlarla gerçekleştirilmesi konuyla ilgili daha derin bilgilere ulaşılması açısından faydalı olabilir.

Öğrenciler, öğretmenler ve öğretmen adaylarıyla; matematiksel düşünmenin tüm alt boyutlarına yönelik deneysel çalışmalar yapılabilir.

$\mathrm{Bu}$ araştırma; farklı okul türlerinde, farklı bölgelerde ve farklı sınıf düzeylerinde uygulanarak sonuçlar MEB'e bildirilebilir. Böylece programların ve ders kitaplarının hazırlanmasında faydalı olabilir.

\section{KAYNAKLAR/ REFERENCES}

Akkoyunlu, B. ve Kurbanoğlu, S. (2003). Öğretmen Adaylarının Bilgi Okuryazarlığı ve Bilgisayar Öz Yeterlik Algıları Üzerine Bir Çalışma. Hacettepe Üniversitesi Eğitim Fakültesi Dergisi, 24, 1-10

Alcı, B., Erden, M. ve Baykal, A. (2008). Üniversite Öğrencilerinin Matematik Başarıları ile Algıladıkları Problem Çözme Becerileri, Özyeterlik Algıları, Bilişüstü Özdüzenleme Stratejileri ve ÖSS Sayısal Puanları Arasındaki Açıklayıcı ve Yordayıcı İlişkiler Örüntüsü. Boğaziçi Üniversitesi Eğitim Dergisi, 25 (2), 53-68.

Alkan, H. ve Bukova-Güzel, E. (2005). Öğretmen Adaylarında Matematiksel Düşünmenin Gelişimi. Gazi Eğitim Fakültesi Dergisi, 25(3), 221-236.

Altun, M. (2002). Matematik Öğretimi. İstanbul: Alfa Yayın Dağıtımı. Bursa

Altun, M. (2005). Eğitim Fakülteleri ve İlköğretim Öğretmenleri İçin Matematik Öğretimi. Aktüel Yayınları,

Ardahan, H. (1990). Matematik Öğretimi, S.Ü. Eğitim Fakültesi Dergisi, 4, 197-205, Konya

Arslan, S. ve Yıldız, C. (2010). 11. Sınıf Öğrencilerinin Matematiksel Düşünmenin Aşamalarındaki Yaşantılarından Yansımalar. Eğitim ve Bilim, 35 (156), 17-31.

Baki, A. (2006). Kuramdan Uygulamaya Matematik Eğitimi, Derya Kitabevi- Trabzon.

Bandura, A. (1986). Social Foundations of Thought and Action: A Social Cognitive Theory, New Jersey: Prentice Hall. 
Baykul, Y. (1999). İlköğretimde Matematik Öğretimi 1 ve 5. Sınıflar. Anı Yayıncılık: Ankara. Tezi. DEÜ. Eğitim Bilimleri Enstitüsü. İzmir

Burton, Leone (1984). Mathematical Thinking: The struggle for meaning. Journal for Research in Mathematics Education, 15(1), 35-49.

Büyüköztürk, Ş., Kılıç Çakmak, E., Akgün, Ö. E., Karadeniz, Ş. ve Demirel, F. (2017). Bilimsel Araştırma Yöntemleri (23. Baskı). Ankara: Pegem Akademi

Coşkun, S. (2012). Üst Düzey Matematiksel Düşünme Süreçlerinin Sorgulayıcı Problem Çözme ve Öğrenme Modeline Göre Tasarlanmış Çalışma Yaprakları Yardımıyla İncelenmesi, Yayınlanmamış Yüksek Lisans Tezi. NECMETTIN ERBAKAN ÜNIVERSITESİ, Eğitim Bilimleri Enstitüsü, Konya

Dede, Y. (2008). Matematik öğretmenlerinin öğretimlerine yönelik öz-yeterlik inançları. Türk Eğitim Bilimleri Dergisi, 6(4), 741-757.

Henderson, P. B., Hitchner, 1. E., Marion, B., Fritz, J., Riedesel, C. P., Hamer, J. ve Scharf, C. (2002). Materials Development İn Support Of Mathematical Thinking. In ACM SIGCSE Bulletin, 35(2), 185-190. Erişim Ad.

https://www.researchgate.net/publication/220613206_Materials_development_in_support_of_mathematical_thinkin $\mathrm{g}$

Göl, R. (2017). 12. sınıf fen lisesi öğrencilerinin matematiksel düşünme becerilerinin özelleştirme, tahmin, ispat ve genelleme basamakları bağlamında incelenmesi. Yayınlanmamış Yüksek Lisans Tezi. UŞAK ÜNIVERSITESİ, Fen Bilimleri Enstitüsü, Uşak.

Karakoca, A. (2011). Altıncı Sınıf Öğrencilerinin Problem Çözmede Matematiksel Düşünmeyi Kullanma Durumları. Yayımlanmamış Yüksek Lisans Tezi. ESKİŞEHİR OSMANGAZİ ÜNIVERSİTESİ. Eğitim Bilimleri Enstitüsü, Eskişehir.

Karasar, N. (2003), "Bilimsel Araştırma Yöntemi”, Nobel Yayınevi, Ankara.

Keskin, M., Akbaba Dağ, S., Altun, M. (2013). 8. ve 11. sınıf öğrencilerinin matematiksel düşünme aşamalarındaki davranışlarının karşılaştırılması. Journal of EducationalSciences. 1(33-50).

Kocaman, M. (2017). Lise 11. sınıf öğrencilerinin matematiksel düşünme ve akıl yürütme becerilerinin incelenmesi, Yüksek Lisans Tezi. BALIKESIR ÜNIVERSITESİ. Fen Bilimleri Enstitüsü, Balıkesir.

Kükey, E. (2018). Ortaokul öğrencilerinin matematiksel düşünme biçimleri ile öğretmen ve öğretmen adaylarının bu konudaki görüşlerinin incelenmesi. Yüksek Lisans Tezi. İNÖNÜ ÜNIVERSİTESİ, Eğitim Bilimleri Enstitüsü, Malatya.

Liu, P. H. (2003). Do Teachers Need To Incorporate The History Of Mathematics İn Their Teaching? The Mathematics Teacher, 96(6), 416.

Mason, J., Burton, L. ve Stacey, K. (1985). Thinking Mathematically. Revised Edition. England: AddisonWesley Publishers, Wokingham.

Milli Eğitim Bakanlığı (MEB) (2009). İlköğretim Matematik Dersi 6-8. Sınıflar Öğretim Programı. Ankara: MEB Basımevi.

Milli Eğitim Bakanlığı (MEB) (2018). Matematik Dersi Öğretim Programı (İlkokul ve ortaokul 1, 2, 3, 4, 5 , 6, 7 ve 8. sinıflar). Ankara: MEB. http://mufredat.meb.gov.tr/ Erişim Tarihi: 01.03.2019.

Mubark, M. M. (2005). Mathematical Thinking And Mathematics Achievement Of Students In The Year 11 Scientific StreamIn Jordan. Ph.D. Thesis, The University of Newcastle, Newcastle, Australia.

Nepal, B. (2016). Relationshipbetween Mathematical Thinking and Mathematics Achievement. Journal Of Advanced Academic Research (JAAR). eISSN: 2362-1311

Öztürk, B. (2017). Ortaokul Öğrencilerinin Üstbilişsel Farkındalık Düzeyi İle Matematik Öz Yeterlik Algısının Matematik Başarısına Etkisinin İncelenmesi. Yüksek Lisans Tezi. ESKİŞEHİR OSMANGAZİ ÜNIVERSITTESİ. Eğitim Bilimleri Enstitüsü. Eskişehir

Pajares, F. ve Miller, M. D. (1994). Role Of Self-Efficacyand Self-ConceptBeliefs in Mathematical Problem Solving: A Path Analysis. Journal of Educational Psychology, 86(2), 193. 116-125

Pajares, F. (2002). Gender and perceived self-efficacy in self-regulated learning. Theory Into Practice, 41(2),

Pilten, P. (2008). Üst Biliş Stratejileri Öğretiminin İlköğretim 5. Sınıf Öğrencilerinin Matematiksel Muhakeme Becerilerine Etkisi. Yayınlanmamış Doktora Tezi. GAZİ ÜNIVERSíTESİ. Eğitim Bilimleri Enstitüsü. Ankara

Polya, G. (1957). How To SolveIt: A new aspect of mathematical method. Second Edition. Princeton: Princeton University Press.

Schoenfeld, A. H. (1992). Learning to Think Mathematically: Problem Solving, Metacognition, and Sensemaking in Mathematics. (Editör: D. Grouws.), Handbook for Research on Mathematics Teaching and Learning, 334-370. New York: MacMillan.

Schunk, D. H. ve Pajares, F. (2002). The Development Of Academic Self-Efficacy. https://doi.org/10.1016/B978-012750053-9/50003-6 
Şenay, Ş. C. (2014). Matematik Öğretmen Adaylarının Sayılar Teorisine Yönelik Soyutlamayı İndirgeme Eğilimlerinin Düşünme Stilleri Ve Matematik Öz Yeterlikleri İle İlişkisinin İncelenmesi. Doktora Tezi. Marmara Üniversitesi Eğitim Bilimleri Enstitüsü: İstanbul.

Tall, D. O. (2002). Advanced Mathematical Thinking. USA: Kluwer Academic Publishers.

Tall, D. O. (2004). Thinking Through Three Worlds of Mathematics, Proceedings of the 28th Conference of the International Groupfor the Psychology of Mathematics Education, PME, Bergen, Norway.

Tall, D. O. (2005). The Transition From Embodied Thought Experiment and Symbolic Manipulation to Formal Proof. Proceedings of Kingfisher Delta'05, Fifth Southern Hemisphere Symposium on Undergraduate Mathematicsand Statistics Teaching and Learning. 1-16. Australia.

Terzi, M. ve Mirasyedioğlu, Ş. (2009). İlköğretim matematik öğretmen adaylarının matematiğe yönelik özyeterlik algılarının bazı değişkenler açısından incelenmesi. TÜBAV Bilim Dergisi, 2 (2), 257-265.

TIMSS (2003). IEA's TIMSS 2003 International Report on Achievement in the Mathematics CognitiveDomains: Findings from a Developmental Project International Associationforthe Evaluation of Educational Achievement. TIMSS \& PIRLS International Study Lynch School of Education, Boston College.

Tuncay, H. A. (2015). Matematiksel Düşünme Süreçlerinin İncelenmesi. Yüksek Lisans Tezi. CUMHURIYET ÜNIVERSITESİ. Eğitim Bilimleri Enstitüsü, Sivas.

Türk Dil Kurumu (TDK). (2019). www.tdk.gov.tr. Erişim tarihi:10.06.2019

Uğurel, I. ve Moralı, S. (2010). Bir Ortaögretim Matematik Dersindeki İspat Yapma Etkinliğine Yönelik Sınıf içi Tartışma Sürecine Öğrenci Söylemleri Çerçevesinde Yakından Bakış, Buca Eğitim Fakültesi Dergisi, 28: 134-154.

Umay, A. (2001). İlköğretim matematik öğretmenliği programının matematiğe karşı özyeterlik algısına etkisi [ The effect of the primary school mathematics teaching program on the mathematics self-efficacy of students]. Journal of Qafqaz University, 8(1). 234-243.

Umay, A. (2003). Matematiksel Muhakeme Yeteneği. Hacettepe Üniversitesi Eğitim Fakültesi Dergisi, 24,

Ünlü, M. ve Ertekin, E. (2018). Matematik öğretmen adaylarının matematik ve matematik öğretimine yönelik özyeterlik inançları: Boylamsal bir çalışma. International Journal of Social Sciences and Education Research Online, http://dergipark.gov.tr/ijsser Volume: 4(1), 2018 ISSN: 2149-5939

Yağdıran, B. (2018). Teknoloji Destekli Öğrenme Ortamlarında 11. Sınıf Öğrencilerinin Matematiksel Düşünme Süreçlerinin İncelenmesi. Yüksek Lisans Tezi. GAZİ ÜNIVERSİTESİ. Eğitim Bilimleri Enstitüsü, Ankara.

Yaman, S. ve Dede, Y. (2006). İlköğretim Öğrencilerinin Matematik Dersine Yönelik Özyeterlik İnanç Düzeyleri Üzerine Bir Çalışma. Türkiye Sosyal Araştırmalar Dergisi, 10 (1-2), 109-119.

Yeşildere, S. (2006). Farklı Matematiksel Güce Sahip İlköğretim 6., 7. Ve 8. Sınıf Öğrencilerinin Matematiksel Düşünme Ve Bilgiyi Oluşturma Süreçlerinin İncelenmesi, Yayınlanmamış Doktora Tezi. DOKUZ EYLÜL ÜNIVERSITESİ, Eğitim Bilimleri Enstitüsü, İzmir.

Yeşildere, S. ve Türnüklü, E. (2007). Öğrencilerin matematiksel düşünme ve akıl yürütme süreçlerinin incelenmesi. Ankara Üniversitesi Eğitim Bilimleri Fakültesi Dergisi, 40(1), 181-213.

Yıldırım, C. (2008). Matematiksel Düşünme (5. Bask1). Remzi Kitapevi, İstanbul: Remzi Kitabevi

Yıldırım, D. (2015). Ortaokul Öğrencilerinin Geometrik Problemlerdeki Matematiksel Düşünme Süreçlerinin İncelenmesi, Yayımlanmamış Yüksek Lisans Tezi, ANADOLU ÜNIVERSİTESİ, Eğitim Bilimleri Enstitüsü, Eskişehir.

Walsh, K. A. (2008). The Relationship Among Mathematics Anxiety, Beliefs About Mathematics SelfEfficacy, And Mathematics Performance İn Associate Degree Nursing Students. Nurs Educ Perspect, 29(4), 226229 


\section{EXTENDED SUMMARY}

\section{INTRODUCTION}

In the literature, researchers have mentioned many elements such as privatization, generalization, hypothesis (prediction) and verification - persuasion (proof), abstraction, synthesis, induction, deduction (Mason and Ark., 1985; Tall, 2002; Liu, 2003; Alkan and Bukova - Güzel, 2005). Self-efficacy is defined as "people's preliminary views about their own capacities in terms of organizing and applying the necessary activities to perform certain performances" (Bandura, 1986).

\section{Research Purpose}

The aim of this study is to determine whether there is a relationship between middle school 6th, 7th and 8th grade students by determining their mathematical thinking stages and their mathematics self-efficacy levels and to examine them according to the mathematics lesson term score variable. Secondary school students who participated in the study for this purpose; mathematics lesson previous term end score, mathematics self-efficacy levels and mathematical thinking stages distribution were analyzed. It was investigated that there was a significant relationship between the students' math lesson end-of-semester scores and both their mathematics self-efficacy scores and their mathematical thinking stage scores.

\section{METHOD}

\section{Research Design}

In this study, relational scanning model, one of the quantitative research methods, was used. Relational research is the study in which the relationship between two or more variables is examined without any intervention to these variables. In the scanning model, the individual, event and object subject to the research are tried to be defined in their own conditions and as they are (Karasar, 2003)".

\section{Study Group}

The study group of the research consists of 415 students from 6th, 7th and 8th grades who study at a public school in the 2017-2018 academic year. However, due to missing data (leaving the questions blank in some worksheets), the worksheets of 27 students were removed from the study and the study was continued with 388 students $(97,128,163$ students respectively). The students participating in the study were selected by simple random sampling method, one of the random sampling methods.

\section{Data Collection Tools}

In the study; A personal information inventory was distributed to the students for the data of the class, 2017 2018 academic year fall term mathematics course final score data. In determining students' mathematical selfefficacy levels, the "Mathematics Self-Efficacy Scale" developed by Umay (2001) was used. In order to determine the mathematical thinking stages of the students, the "Mathematical Thinking Stages Determination Scale", which consists of 4 sub-dimensions (privatization, generalization, hypothesis and persuasion / reasoning / proving) and includes 3 different worksheets, was used. Two of the worksheets were developed by the researcher. One of them belongs to Keskin, Akbaba Dağ, and Altun (2013).

\section{Data Analysis}

The data obtained as a result of the application were analyzed using the SPSS 22.0 package program. Pearson Chi-Square Test and Spearman Rank Differences Correlation coefficient technique was used, and the significance in comparisons was tested at (p) 0.05 level. If the difference between the compared groups was significant, the effect size value was checked. For the effect size obtained in the chi-square tests, the interpretation was made considering the degree of freedom of the Cramer'sV value.

\section{FINDINGS}

Normality analyzes of the results of Mathematics Self-Efficacy Levels and Mathematical Thinking Stages scales were made and nonparametric analyzes were used because the data did not show normal distribution. In this study; "Is there a significant relationship between middle school students' mathematical thinking stages and their mathematical self-efficacy?" For the findings related to the problem, the significance of the difference between mathematical thinking stages and mathematics self-efficacy levels was examined and interpreted with the Pearson Chi-Square Test. Afterwards, Spearman Rank Differences correlation analysis was performed on the basis of points to determine the relationship between them. After all; It was observed that there was a moderately significant positive relationship between students' mathematical thinking stages and mathematics self-efficacy. 


\section{DISCUSSION AND CONCLUSION}

While determining the mathematical thinking stages of the students in the study, most of the questions about the privatization stage were answered correctly. The reason for this may be that while mathematics and mathematics applications lessons are being taught in schools, emphasis may be placed on special questions and procedural knowledge. As we progress towards the stages of generalization, making assumptions and persuasion (verification, proving), the number of students reaching these stages decreases. Mathematical Thinking; Verbal expressions and arithmetic operations were preferred more in the stages of generalization, assumptions, and persuasion, and mathematical expressions were less common. In the second sub-problem, a moderately significant positive correlation was found between the mathematics course fall term scores and mathematics self-efficacy scores of the students. This result; This may indicate that students with high math end-of-term scores may also have a high perception of mathematics self-efficacy. In the third sub-problem, it was observed that there was a moderately significant positive correlation between the mathematics course fall term scores and mathematical thinking stages scores of the students. It can be thought that the increase in mathematical thinking stages as students' mathematics course end-of-fall scores increase, as they study mathematics, and thus, the development of skills such as assumption, prediction and interpretation. Finally, it was investigated whether there is a relationship between the mathematical thinking stages of the students, who constitute the title of the study, and their mathematical selfefficacy, and a significant difference was found. Then, the relationship between the scores of mathematical thinking stages and mathematics self-efficacy was examined, and a moderate positive relationship was found between them. Here, it was concluded that students with high level of mathematics self-efficacy rise to the upper levels of mathematical thinking stages. 